\title{
Ülseratif Kolitin Pediatrik Bakımı ve Kavram Haritası
}

\author{
The Pediatric Ulcerative Colitis Concept Map and Pediatric Care \\ Merve GÜMÜŞ ${ }^{1}$, Şeyda BİNAY YAZ ${ }^{2}$, Selmin ŞENOL ${ }^{3}$
}

\begin{abstract}
ÖZ
Hemşirelikte bakım, eğitim, öğretim, yönetim ve araştırma gibi alanlarda işlerin planlanmasında, kavram haritaları birer rehber olarak kullanılmaktadır. $\mathrm{Bu}$ kavram haritaları, öğrenen kişinin bilgiyi düzenleyerek ve analiz ederek temel kavramları tanımlamasını, grafiksel olarak görüntülemesini ve bağlant1 kurabilmesini sağlayan bir öğrenim stratejisidir. Literatür bilgisi, kavram haritalarının hemşirelik bakım planına bir seçenek olabileceğini, zaman kazandırdığı, evrak işlerini azalttığı ve kontrol listesi mantığ 1 ile ilerlediği için hata riskini azalttığını belirtmektedir. Pediatride kritik bir yere sahip olan inflamatuvar barsak hastalıkları, hemşirelik bakım sürecinin yönetilmesi ve çocuk/ aile bakımı açısından oldukça önemlidir. İnflamatuvar barsak hastalığı olan ülseratif kolit, gen mutasyonu yanı sıra çevresel ve immünolojik etkenlerin bir araya gelmesi ile oluşan kronik bir hastalıktır. Çocukta beslenme, sindirim, emilim, boşaltım gibi birçok sistem fonksiyonunu etkilemektedir. Bu olgu sunumunda, "Ülseratif Kolit" tanısı ile takip edilen çocuğun, "Kavram Haritası" kullanılarak hemşirelik bakım planının sunulması amaçlanmıştır.
\end{abstract}

Anahtar Kelimeler: Ülseratif Kolit, Pediatri, Kavram Haritası, Hemşirelik Bakımı

\begin{abstract}
Concept maps are used as a guide for planning the process in nursing care, education, training, management and research. These concept maps are learning strategy that enable the learner to define, graphically display and connect to basic concepts by organizing and analyzing information. It is stated in the literature that concept maps can be an option to the nursing care plan and this can reduce the risk of errors as it saves time, reduces paperwork and progresses with the checklist logic. Managing the inflammatory bowel diseases, nursing care process, which has a critical place in pediatrics, is very important for both the child and the family. Ulcerative colitis, an inflammatory bowel disease, is a chronic disease caused by gene mutation, the combination of environmental and immunological factors. It affects many system functions such as nutrition, digestion, absorption and excretion in the child. We aimed to present nursing care using a concept map in a pediatric patient with ulcerative colitis.
\end{abstract}

Keywords: Ulcerative colitis, Pediatrics, Concept Map, Nursing Care.

Olgunun yazılı onamı annesi G.M'den, sözlü onamı kendisinden alınmıştır. Bu olgu daha önce kongrede sunulmamıştır.

${ }^{1}$ Ar. Gör., Merve GÜMÜŞ, Çocuk Sağlığı ve Hastalıkları Hemşireliği Anabilim Dalı, Ege Üniversitesi, Hemşirelik Fakültesi, mervedalgic10@gmail.com, ORCID: 0000-0003-1856-179X

${ }^{2}$ Dr. Öğr. Üyesi Şeyda BİNAY YAZ, Hemşirelik Bölümü, İzmir Bakırçay Üniversitesi, Sağlık Bilimleri Fakültesi, seydabinay80@gmail.com, ORCID: 0000-0001-6410-6240

${ }^{3}$ Prof. Dr., Selmin ŞENOL, Çocuk Sağlığı ve Hastalıkları Hemşireliği Anabilim Dalı, Kütahya Sağlık Bilimleri Üniversitesi, senolselmin@yahoo.com ORCID: 0000-0003-4716-3512 


\section{GíRiş}

Hemşirelik, uygulamalı bir disiplin olarak yenilikçi öğrenme yöntemlerine son derece açıktır. Özellikle son yıllarda, bu yöntemler öğrenme sürecini hızlandırmayı hedeflediği kadar, karar vericilik noktasındaki hemşirelik uygulamalarına eleştirel bir bakış kazandırmayı da hedeflemektedir. Hemşirelik öğrencisinin, eğitim sürecinde sorunu nasıl saptayacağı, nasıl analiz edeceği ve bilgileri nasıl bir araya getireceğini kavraması ezber anlayışının dışında bir yaklaşımdır. $\mathrm{Bu}$ nedenle başlangıçta zor ve karmaşık olarak görülür. Oysaki, neden sonuç ilişkisinde planlı bir yol akışı izlendiğinde öğrenme anlam kazanmaya başlar ve güvenli adımlarla sonuca doğru ilerleme sağlanır. Hemşirelikte öğretim yöntemlerinden birisi öğrencilerin bilgilerini açık bir grafik haritada çizdikleri kavram haritasıdır. ${ }^{1}$ Kavram haritası, öğrenen kişinin bilgiyi düzenleyerek ve analiz ederek temel kavramları tanımlamasını, grafiksel olarak görüntülemesini ve bağlantı kurabilmesini sağlayan bir öğrenim stratejisidir. ${ }^{2}$ Kavram haritasının temeli David Ausubel'in anlamlı öğrenme teorisine dayanmaktadır. Ausubel'e göre öğrenen kişi gerçek bilgiye ezberleyerek ulaşamaz ve yeni bilgi ancak aktif olarak zihinde bulunan içerik ile bağlantı kurulduğunda ortaya çıkar. ${ }^{3}$ Kavram haritasının amac1 yeni bir bilginin ezberlenerek değil bilgiler arasında bağlantı kurularak öğrenilmesidir. $\mathrm{Bu}$ teoriden yola çıkarak Novak 1972-1992 yılları arasında kavram haritasını bir öğrenme aracı olarak tanımlamıştır ve kavram haritası oluşturmak üzere web tabanlı bir uygulama (CmapTools) geliştirmiştir., ${ }^{4,5}$ Günümüzde ise web tabanlı, akıllı telefonlarda kullanılabilen birçok kavram haritası uygulamas1 (concept mapping applications) kullanılmaktadır.

Kavram haritası birbiri ile bağlantılı kavramları doğrudan ve/veya çapraz bağlantı kurarak olguları açıklayan görsel sunumlardır. Kişi, kendini ifade ediş şekli ve deneyimlerinden etkilendiği için, her bir kavram haritası eşsizdir. ${ }^{6}$ Kavram haritaları genellikle kutucuklar, daireler ya da diğer geometrik şekiller kullanılarak oluşturulur ve birçok formda olabilir fakat genel olarak dört majör, üç minör tipten oluşmaktadır. Ana tipler; örümcek haritalar, hiyerarşik düzenli haritalar, akış şemaları ve sistem haritaları iken, resimsel manzara formatlı harita, çok boyutlu harita ve mandala (çember) harita alt tipleridir. $^{1}$

Eğitimde kavram haritasının önemli bir yeri olmasına rağmen ülkemizde lisans düzeyinde kullanımı yaygın değildir. Yapılan çalışmalarda öğretim stratejisi olarak kavram haritası kullanımının kritik düşünme becerisini arttırdığ 1 , öğrencilerin bilgiyi organize etmesini kolaylaştırdığ gösterilmiştir. ${ }^{1,7-11}$ Ulusal literatürde kavram haritası yoluyla incelenmiş olgu sunumları vardır. $^{12,13}$ Ayrıca kavram haritalarının hemşirelik bakım planına bir seçenek olabileceğini ve bunun zaman kazandırdığ evrak işlerini azalttığ 1 ve kontrol listesi mantığ 1 ile ilerlediği için hata riskini

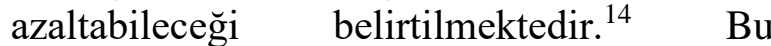
makalede, kavram haritasından yola çıkılarak hazırlanan pediatrik ülseratif kolit olgusunun bakım süreci sunulmuştur.

İnflamatuvar barsak hastalıkları kronik ve tekrarlayıcı bozukluklardır. Bunlar Crohn hastalığ 1 , ülseratif kolit ve indetermine kolit olmak üzere üç hastalık grubunu içermektedir. Hem gen mutasyonu hem de çevresel ve immünolojik etkenlerin bir araya gelmesi ile oluşan inflamatuvar bir hastalıktır. ${ }^{15}$ Ülkemizde ülseratif kolit insidans1 2,6/100.000 iken çocuklarda bu oran 0,5-4,3/100.000 olarak bildirilmiştir. ${ }^{16,17}$ Erkek ve k1z çocuklarda eşit sıklıkla ve genellikle 10 yaş civarında görülmektedir. Dünyada, kolite en sik neden olan parazitin Entamoeba Histolytica olduğu bildirilmiştir. ${ }^{17}$ Kavram haritası ile bakım süreci yapılan olgunun tanitım bilgileri Fonksiyonel Sağlık Örüntüleri doğrultusunda aşağıda yer almıştır. Şekil I'de de ülseratif kolit hastalığının genel bilgileri yer almaktadır. 


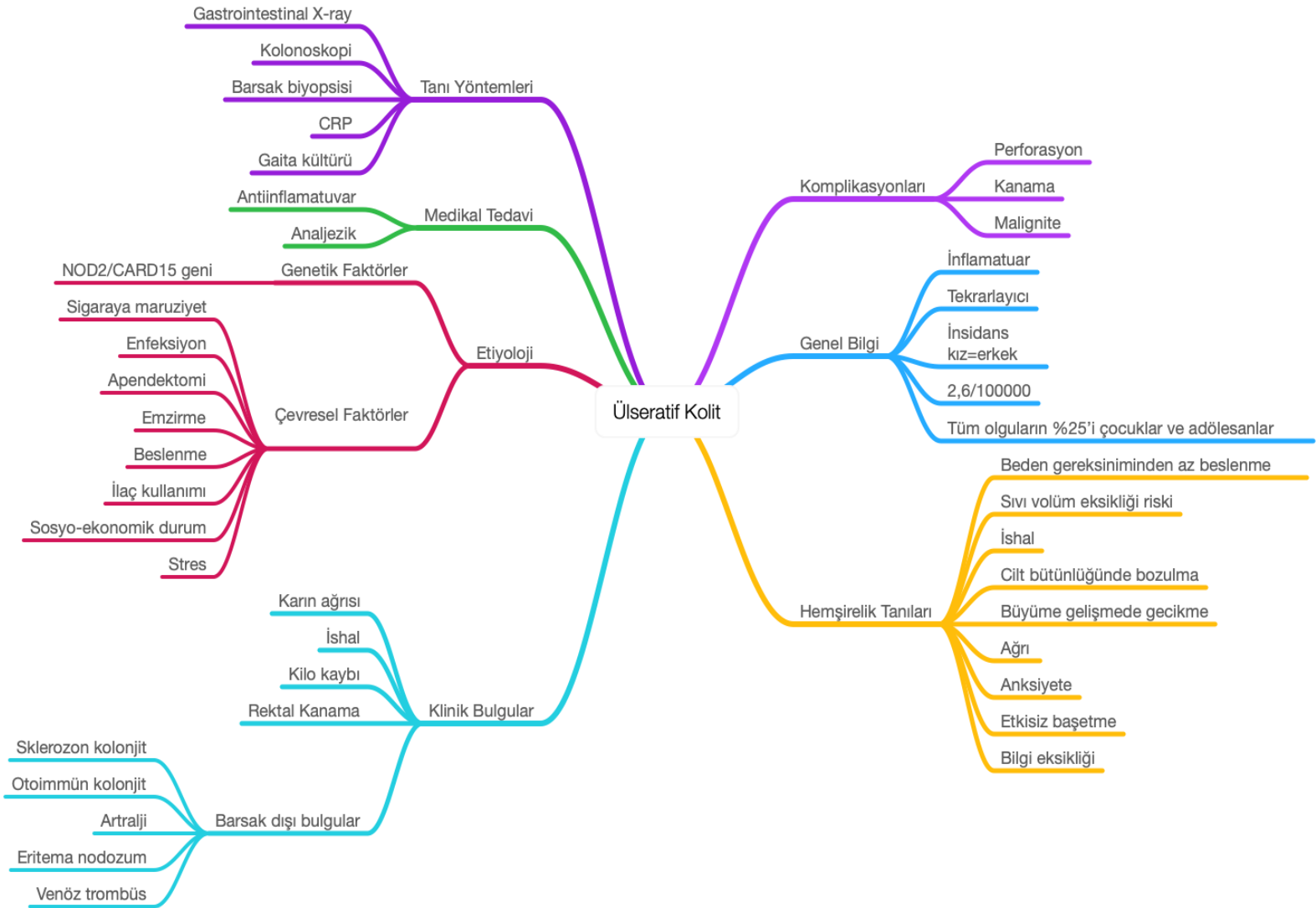

Şekil 1. Ülseratif Kolit Genel Bilgiler Kavram Haritası

\section{OLGU SUNUMU}

\section{Fonksiyonel Sağlık Örüntülerine Göre Veri Toplama}

Olgunun verileri yüz yüze görüşülerek bakım verilme süresi boyunca toplanmıştır. Veri toplamanın amaci K.M'nin annesi G.M.'ye açıklanmıştır ve kendisinden yazılı oğlu K.M.'den sözlü onam alınmıştır.

Ad: K.M.

Yaş: 12

\section{Cinsiyet: Erkek}

Ağırlık:30 kg (\%3 persentil)

Boy: $153 \mathrm{~cm}$ (\%50 persentil)

Tanı: Ülseratif Kolit

Klinik: Pediatrik Gastroenteroloji Kliniği

\section{A. Sağlığı Algılama-Sağlığı Yönetme Örüntüsü}

K.M 12 yaşında erkek çocuktur. Yedisekiz aydır ishal, kilo kaybı, halsizlik ve iştahsızlık şikayetleri ile bir üniversitenin genel pediatri servisine başvurmuştur. İlk olarak K.M.'de demir eksikliği anemisi tanısıyla tedaviye başlanmıştır. İki- üç hafta daha şikayetlerin devam etmesi üzerine hastaneye yatışı yapılmıştır. İshali devam eden olgunun gaita kültürü normal olup parazit testinde Entamoeba Histolytica paraziti saptanmıştır.

Direk batın grafisi: Megakolon tarzında genişleme.

Kolonda genişleme ve makroskopide yaygın ülserasyonlar nedeniyle sadece rektum ve sigmoid kolona bakilan hastada Ülseratif Kolit tanısı konulmuştur.

Medikal tedavi: Salazopyrin $50 \mathrm{mg} / \mathrm{kg}$, Deksametazon $2 \mathrm{mg} / \mathrm{kg}$ başlanmıştır.

Özgeçmiş: Normal spontan vajinal doğum ile 3450 gr dünyaya gelmiş, hiperbilirubinemi tanısıyla fototerapi almış. 
Aşıları tam. S1k sık otit gelişen K.M'de başka bir hastalık öyküsü yoktur.

Soygeçmiş: Özellik yoktur.

Laboratuvar Bulguları: $\mathrm{Hb}: 7,1 \mathrm{gr} / \mathrm{dL}$, Hct \%20, WBC: $18100 \mathrm{~mm}^{3}$, PLT: 550,0000 $\mathrm{mm}^{3}$, Fe: $23 \mathrm{mic} / \mathrm{dl}$, total protein: 5,5 gr/dl, Albümin $3 \mathrm{gr} / \mathrm{dl}$, elektrolitler normal.

\section{B. Beslenme-Metabolik Örüntü}

K.M. tuzsuz R3 diyet ile besleniyor. Laksatif etkili besinlerle (üzüm, kayısı, erik) aşırı yağlı besinlerin tüketimi yasak.

İshal devam ettiği ve hafif dehidrate olduğu için günlük sıv1 alımı $2100 \mathrm{ml}$ 'dir. Sıv1 dengesi eksi 200-300cc arasında izlenmiştir. Genel durumu halsiz, soluk, turgor basinc1 azalmıştır.

\section{Boșaltım Örüntüsü}

Barsak sesleri 11-15/dk aras1 olan K.M'nin günde 5-6 sulu gaita çıkışı mevcut. İdrar yapmada sorun gözlenmedi. Rektal tuşede parlak kırmızı kanama mevcut.

\section{Aktivite-Egzersiz Örüntüsü: Fizik Bulgular}

Kalp atım hizı 104/dk, solunum hizı 30/dk, oksijen satürasyonu \%98-100, kan basinc1 91/52 mmHg. Özbakım gereksinimleri bakım verici annenin ve hemşirenin destekleri ile karşılanmaktadır. Halsiz olması nedeniyle günün büyük kısmını yatakta geçiriyor.

\section{E. Uyku-Dinlenme Örüntüsü}

Gece uykusu 11 saat, gündüz uykusu 2-3 saat olarak kaydedilmiştir.

\section{F. Kendilik Algısı-Benlik Kavramı Örüntüsü}

Daha önce hastaneye yatış öyküsü bulunmayan K.M kendini endişeli hissettiğini ve arkadaşlarından ayrı olduğu için mutsuz olduğunu ifade etmiştir. Bir futbol kulübüne üye olan K.M, beslenmesine çok dikkat ettiğini ve kendini hasta edecek şeylerden uzak durmasına rağmen neden bu hastalığın onu bulduğunu sorgulamaktadır.

\section{G. Rol-İlişki Örüntüsü}

KM'nin annesi 35 yaşında ev hanımı, babası 41 yaşında KM'nin oynadığı futbol kulübünün antrenörü olarak çalışmaktadır. Annesi ile daha yakın bir iletişim sergileyen olgunun zaman zaman babasıyla çatıştığı öğrenilmiştir.

\section{H. Stresle Başetme Örüntüsü}

K.M kendini genel olarak sakin ve uyumlu olarak tanımlıyor. Annesine sik sik "benim için dua et hemen iyileşeyim artık futbol oynamak istiyorum" dediği öğrenildi. Annesinin dualarının onu iyileştireceği inancinda.

\section{Cinsellik ve Üreme Örüntüsü}

K.M'nin genital bölgesinde tüylenme başladığı annesinden öğrenilmiştir. Genital bölge temizliği konusunda anne ya da babanın henüz bilgilendirme yapmadığı öğrenilmiştir.

\section{İ. Bilişsel Algılama Örüntüsü}

K.M. gün içerisinde ağrısını 4-5 olarak tanımlıyor. Ağrı karın bölgesinde ve kramp tarzında. Artık arkadaşlarıyla vakit geçirmek istediğini ve çok sıkıldığını ifade etmiştir.

\section{J. Değer ve İnançlar}

K.M. Allah inancı olan bir çocuk ve annesinin dualarının onu rahatlattığını söylüyor. K.M' nin verileri ile hemşirelik bakımı, hastalık patofizyolojisi üzerinden kavram haritası ile şekil II'de sunulmuştur. Şekil III'de hemşirelik bakım planı verilmiştir.

\section{Araştırmanın Etik Yönü}

$\mathrm{Bu}$ çalışma kurumda yapılmış bir araştırma değil kişi-olgu ile yapılmış ve kişiden ve yakınından sözlü ve yazılı onamlar alınmıştır. 


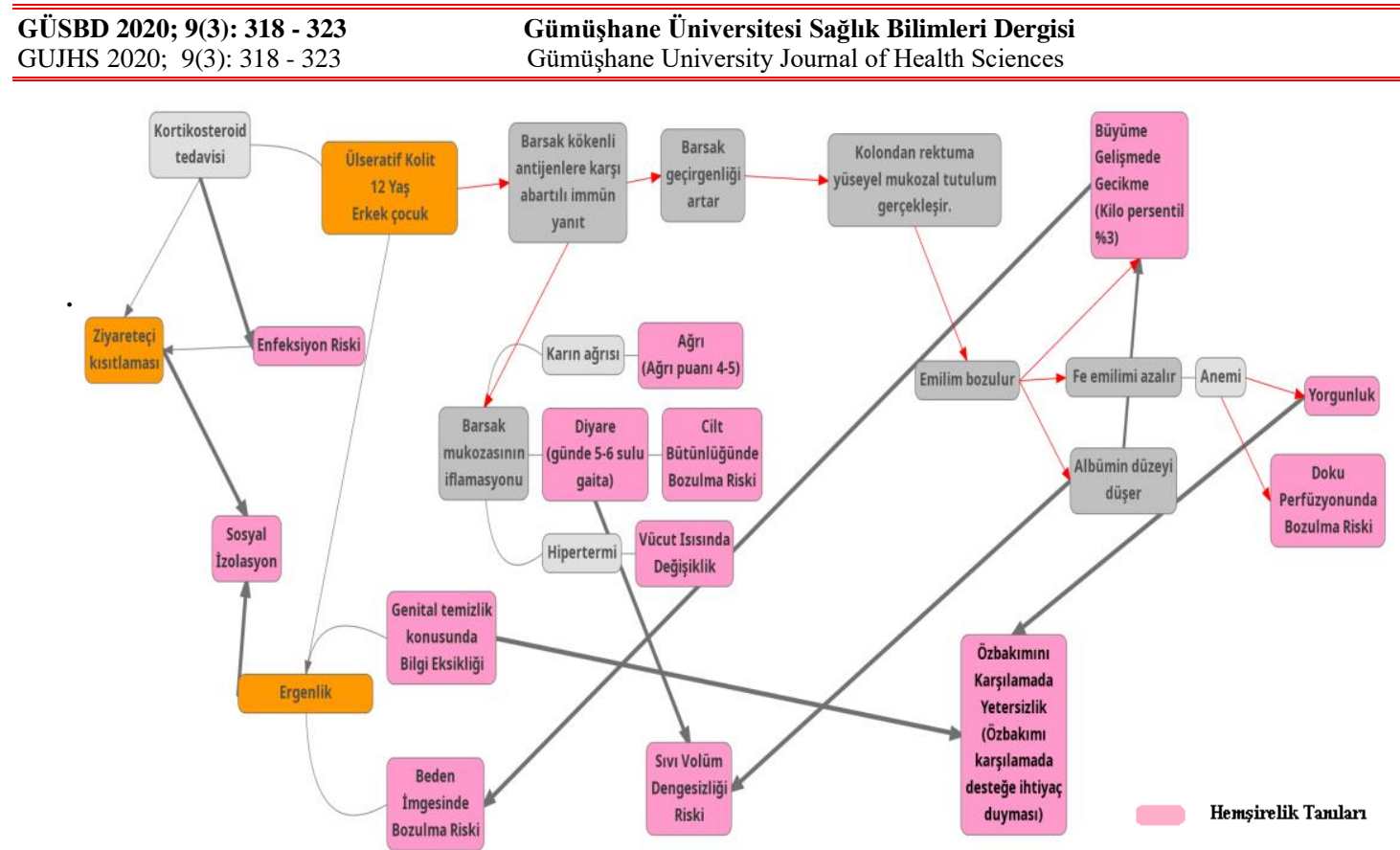

\section{Şekil 2. Ülseratif Kolit Olgusuna Yönelik Kavram Haritası}

Ülseratif kolit kronik bir barsak hastalığıdır. Hastalıkta tedavi süreklidir ve tedaviye rağmen atak dönemleri görülebilir. Ataklar uygun terapötik yönetim ile azaltılabilir. On iki yaşındaki ülseratif kolit olgusunun ele alındığı bu makalede, hemşirelik bakımı sonrasında, çocuk ve bakım verici annenin soruları yanıtlanmış, gereksinim olarak tanımlanan alanlarda bilgilendirmeler yapılarak öz bakımını mümkün olduğunca kendisinin yapmas1 sağlanmıştır. Ayrıca çocuğun ve bakım verici annenin teröpatik rejimi etkili yönetmeye başladığı gözlenmiştir. Aile ve çocuğun tedavi sürecini kabullenmesi tedaviye uyumu güçlendirmiştir. Taburculuk sonrasi ataklar arasında sosyal aktivitelere (arkadaşlarıyla görüşme, futbol) istekle katıldığ 1 ögrenilmiştir.

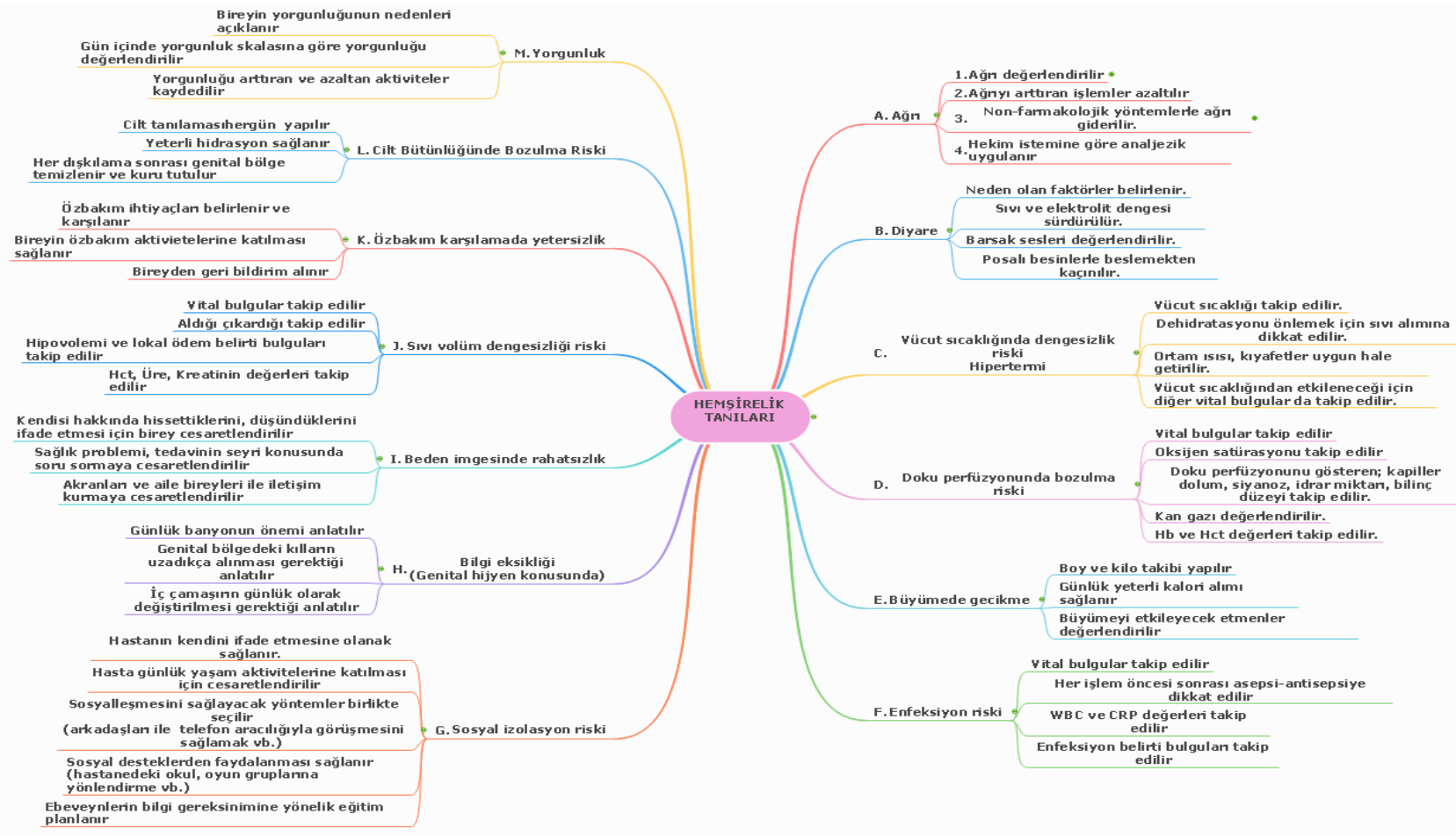

Şekil 3. Olgunun Hemşirelik Tanıları ve Girişimleri 


\section{SONUÇ VE ÖNERILLER}

Kavram haritası, öğrencilerin bilgileri organize ve analiz ederek temel kavramları tanımlamasını, bağlantılarını grafiksel olarak göstermesini gerektiren bir öğretim stratejisidir. Kavram haritası, eleștirel düşünme becerilerinin geliştirilmesinde bir öğrenme aracı olarak kullanılmaktadır. Yapılan çalışmalarda, bakım sürecinde kavram haritası kullanan öğrencilerin akademik başarılarının daha yüksek olduğu bildirilmiştir. ${ }^{1,7,8,18}$

Hemşirelik bakım sürecinin kavram haritası yoluyla sunulması ögrrencilerin;

$\bullet \quad$ Neden sonuç ilişkisi
kurmalarını,

\author{
- Olguyu bütüncül olarak \\ görmelerini,
}

- Öğrenmeyi kolaylaştırarak bakım sürecini eğlenceli hale getireceği,

- $\quad$ Akademik başarıyı arttıracağı düşünülmektedir.

$\mathrm{Bu}$ nedenle kavram haritasinın lisans ve lisansüstü düzeyde hemşirelik eğitiminin içinde yer alması önerilmektedir. Ayrıca öğrenciler, kavram haritasını bir öğrenme stratejisi olarak kullanmaları konusunda cesaretlendirilmelidir.

\section{KAYNAKÇA}

1. All, AC, Huycke, LI, Fisher, MJ. (2003). Instructional tools for nursing education: Concept mapping. Nurs Educ Perspect. 24 (6) 311-7. Available from: https://www.ncbi.nlm.nih.gov/pubmed/14705401

2. Romance, NR, Vitale, MR. (1999). Conceptmapping as a tool for learning: Broadening framework student-centered instruction.College Teaching, 47, 74-79.

3. Daley, BJ, Shaw, CR, Balistrieri, T, Glasenapp, K, Piacentine, L. (1999). Concept maps: a strategy to teach and evaluate critical thinking. J Nurs Educ. 38, 42-7.

4. Gul, RB, Boman, JA. (2006). Concept mapping: A strategy for teaching and evaluation in nursing education. Nurse Educ Pract. 6, 99-206.

5. Novak, JD, Cañas, AJ. (2008). The Theory UnderlyingConcept Maps and How to Construct and Use Them. Technical Report IHMC CmapTools. Florida Institute for Human and Machine Cognition. http:// cmap.ihmc.us/Publications/ResearchPapers/TheoryUnderlying ConceptMaps.pdf (15.03.2013).

6. All, A.C, Havens, RL. (1997). Cognitive/concept mapping: A teaching strategy for nursing. Journal of Advanced Nursing, 25, 1210-1219.

7. Aein, F, \& Aliakbari, F. (2017). Effectiveness of concept mapping and traditional linear nursing care plans on critical thinking skills in clinical pediatric nursing course. Journal of education and health promotion, 6 (13). doi: 10.4103/jehp.jehp_49_14

8. Atay, S, Karabacak, Ü. (2012). Care plans using concept maps and their effects on the critical thinking dispositions of nursing students. International Journal of Nursing Practice, 18 (3), 233239.

9. Hsu, L, Hsieh, SI. (2005). Concept maps as an assessment too in a nursing course. Journal of Professional Nursing, 21 (3), 141-149.

10. Kha BA, Al F, Vazi N, Barolia, R, Rehan S. (2012). Students perceptions of clinical teaching and learning strategies. Nurse Educ Today. 32, 85-90. doi: 10.1016/j.nedt.2011.01.016.
11. Moattari, M, Soleimani, S, Moghaddam, NJ, Mehbodi, F. (2014). Clinical concept mapping: Does it improve disciplinebased critical thinking of nursing students? Iranian journal of nursing and midwifery research, 19 (1), 70.

12. Öztürk, C, Karayağız, G. (2006). Teori ile Uygulama Arasında Yeni Bir Köprü: Kavram Haritası. C.Ü. Hemşirelik Yüksekokulu Dergisi. 10 (1), 29-36.

13. Uslu, N, Korkmaz, Z, Tosun, Ö, Avcı, Ö, Bayat, M, Erdem, E. (2013). Kavram Haritasının Öğrenci Eğitiminde Kullanımına Bir Örnek: Tip 1 Diabetes Mellitus. ERÜ Sağlık Bilimleri Fakültesi Dergisi, 1 (1), 99-105.

14. Schuster, PM. (2000). Concept Mapping: Reducing Clinical Care Plan Paperwork and Increasing Learning. Nurse Educator, 25 (2), 76-81.

15. Baysoy, G. (2013). İnflamatuvar Bağırsak Hastalıkları. İçinde; Cocuk Gastroenteroloji, Hepatoloji ve Beslenme. Özden, $\mathrm{H}$, Yüce, A, Gürakan, F, Saltık Temiz İN., Demir, H. (Ed.). Akademi Yayınevi; İstanbul.

16. MKoma, AE (2013). Inflammatory bowel disease: an expanding global health problem. Clin Med Insights Gastroenterol, 33-47.

17. Buran, T. (2017). İnflamatuar Barsak Hastalığında Epidemiyoloji, Prevalans ve İnsidans. Turkiye Klinikleri J Gastroenterohepatol-Special Topics, 10 (1), 15-7.

18. Jaafarpour, M, Aazami, S, Mozafari, M. (2016). Does concept mapping enhance learning outcome of nursing students? Nurse education today, 36, 129-132. 